(NCCN) (2020), Non-small cell lung cancer, NCCN Clinical Practice Guidelines in Oncology, Version 3.2020

4. Dela Cruz C.S., Tanoue L.T., and Matthay R.A. (2011). Lung Cancer: Epidemiology, Etiology, and Prevention. Clinics in Chest Medicine, 32(4), 605-644.

5. Tomasini P., Barlesi F., Mascaux C., et al. (2016). Pemetrexed for advanced stage nonsquamous non-small cell lung cancer: latest evidence about its extended use and outcomes:. Therapeutic Advances in Medical Oncology.

6. Hanna N., Shepherd F.A., Fossella F.V., et al. (2004). Randomized phase III trial of pemetrexed versus docetaxel in patients with non-small-cell lung cancer previously treated with chemotherapy. J Clin Oncol, 22(9), 1589-1597.

7. Pujol J.-L., Paul S., Chouaki N., et al. (2007). Survival without common toxicity criteria grade $3 / 4$ toxicity for pemetrexed compared with docetaxel in previously treated patients with advanced nonsmall cell lung cancer (NSCLC): a risk-benefit analysis. J Thorac Oncol, 2(5), 397-401.

8. Bùi Công Toàn- Hoàng Đình Chân (2008), Bênh ung thư phổi, Nhà xuất bản $Y$ hoc.

9. Trânn Nguyên Bảo (2014). Đánh giá hiệu quả điều tri Docetaxel trong điêu tri bước 2 UTPKTBN tai Bênh viên Ung Bướu Hà Nội. Luân văn thạc sĩ Y học, Đ̇ại Học Y Hà Nội.

\title{
TÌNH TRẠNG CĂNG THẲNG CỦA NHÂN VIÊN Y TẾ TẠI MộT SỐ BÊNH VIÊ̂N ĐIỀU TRI BỆNH NHÂN COVID-19 TẠI THÀNH PHỐ HỒ CHÍ MINH NĂM 2021
}

\author{
Vũ Thị Cúc ${ }^{1}$, Nguyễn Phúc Thành Nhân ${ }^{1}$, Nguyễn Xuân Chi ${ }^{2}$, \\ Nguyễn Võ Minh Hoàng ${ }^{2}$, Võ Văn Thắng ${ }^{1,3}$, Nguyễn Minh Quân ${ }^{2}$
}

\section{TÓM TẮT}

Đă̆t vấn đề: Nhân viên y tế là đối tượng tiếp xúc trực tiếp với cảm xúc tiêu cực ở mức độ cao dường như làm tăng nguy cơ dẫn đến hậu quả lâu dài như căng thẳng thứ phát, các triệu chứng trầm cảm hoăc kiệt sức nghề nghiệp với các kết quả bất lợi đến chất lượng chăm sóc sức khỏe. Mục tiêu: Đánh giá mức đổ căng thẳng của nhân viên y tế và môt số yếu tố liển quan tại một số bệnh viện điều trị bệnh nhân COVID-19 tai thành phố Hồ Chí Minh nẳm 2021. Phương pháp: Thiết kế nghiên cứu mô tả cắt ngang được thực hiện trên 244 nhân viên y tế tại 12 bệnh viện, cơ sở y tế tuyến đầu điều trị COVID-19 tại thành phố Hồ Chí Mình. Sử dụng cấu phần căng thẳng từ thang đo Trầm cảm - Lo âu - căng thẳng (DASS-21) để đánh giá mức độ căng thẳng của nhân viên y tế. Kết quả: Trong 244 nhân viên y tế tham gia nghiên cứu, tỷ lệ có tình trạng căng thẳng là $80,3 \%$, trong đó tỷ lệ có căng thẳng ở mức độ rất nặng, nặng, vửa và nhe lần lướt là: $12,3 \%, 27,9 \%, 22,5 \%$ và $17,6 \%$. Phẩn tích hồi quy logistic cho thây có 2 yếu tố liên quan đến tình trạng căng thẳng ở nhân viên y tế bao gồm: trực tiếp tham gia điều trị bệnh nhân COVID-19 $(\mathrm{OR}=2,14,95 \% \mathrm{CI}: 1,01-4,53 ; \mathrm{p}<0,05)$ và thường xuyên chiu áp lực từ cấp trên trong công việc ( $O R=$ 7,05; 95\%CI: 1,55 - 31,9; $p<0,05)$. Kết luận: Tỷ lệ nhân viên y tế có tình trạng căng thẳng rất cao. Cần

${ }^{1}$ Viện Nghiên cứu Sức khỏe Cộng đồng, Trường Đại hoc Y Dược, Dại họ Huê

̇ệnh viện thành phố Thủ Đức, Hồ Chí Minh

${ }^{3}$ Trường Đại học Y Dược, Đại học Huế

Chiu trách nhiệm chính: Nguyễn Minh Quân

Email: tsminhquanbvtd@gmail.com

Ngày nhận bài: 16.8.2021

Ngày phản biên khoa họ: 12.10.2021

Ngày duyệt bài: 19.10.2021 giảm thời gian làm viêc và tăng cường chính sách đảm bảo an toàn môi trường bệnh viện, đặc biệt quan tâm nhiều hơn cho nhân viên y tế tiếp xúc trực tiếp với bệnh nhân COVID-19 tron quá trình điều trị

Từ khóa: Căng thẳng, nhân viên y tế, COVID-19, thành phố Hồ Chí Minh

\section{SUMMARY \\ STRESS AMONG MEDICAL WORKERS IN SOME HOSPITALS TREATING COVID-19 PATIENTS IN HO CHI MINH CITY}

Background: Medical workers are directly exposed to high levels of negative emotions that appear to increase the risk of long-term consequences such as secondary stress, depressive symptoms or burnout occupation with adverse outcomes for health care quality. Objectives: To assess the stress level of medical workers and its related factors at some hospitals treating COVID-19 patients in Ho Chi Minh City in 2021. Methods: A cross sectional study was conducted on 244 medical workers in 12 hospitals and frontline medical units treating COVID-19 patients in Ho Chi Minh City from September 13 to 20, 2021. Using the stress component of the 21-item Depression, Anxiety and Stress Scale (DASS-21) to assess the level of stress among healthcare workers. Results: A total of 244 medical workers, $80.3 \%$ experienced stress. The prevalence of stress was found to be in the range of mild $(17.6 \%)$, moderate $(22.5 \%)$, severe $(29.7 \%)$, of extremely severe $(12.3 \%)$. Multivariable logistic regression model showed that directly treating COVID-19 patients $(\mathrm{OR}=2.14$, 95\%CI: 1.01 - 4.53; $\mathrm{p}<0.05)$ and often under pressure from superiors at work $(\mathrm{OR}=7.05$; 95\%CI: 1.55 - 31.9; $p<0.05)$ were associated with stress. Conclusion: The prevalence of stress among medical workers was very high. It is necessary to reduce working time and strengthen special policies to ensure the highest level of safety in hospital 
environment, especially paying more attention to medical workers who having direct contact with COVID-19 patients during treatment.

Keywords: Stress, medical workers, COVID-19, Ho Chi Minh city.

\section{I. ĐẶT VẤN ĐỀ}

Tình trạng khẩn cấp về sức khỏe do đại dịch COVID-19 đã ảnh hưởng nặng nề đến sức khỏe tâm lý và tình cảm của người dân nói chung và nhân viên y tế (NVYT) nói riêng. Ở các NVYT tuyến đầu chống dịch, các nguyên nhân khác nhau của tình trạng đau khổ tâm lý đã được báo cáo, chẳng hạn như không chắc chắn về tiến triển của bệnh, điều trị, thiếu thiết bị bảo vệ cá nhân, suy kiệt cơ thể, khối lượng công việc quá tải, lo ngại về tiếp xúc trực tiếp với COVID-19 tại nơi làm việc, đặc biệt, có liên quan đên nỗi sợ bị lây nhiễm giữa các đồng nghiệp và các thành viên trong gia đình $[1-3,7]$. Ngoài ra, NVYT có nguy cơ phát triển rối loạn căng thẳng thứ phát [5].

Kết quả từ các nghiên cứu được thực hiện trong các bối cảnh tương đương như Hội chứng hô hấp cấp tính nặng (SARS) hoặc Hội chứng hô hấp Trung Đông (MERS), nhấn mạnh rằng NVYT trải qua mức độ căng thẳng, lo lắng và các triệu chứng trầm cảm cao, căng thẳng tâm lý và các triệu chứng căng thẳng sau chấn thương bao gồm lảng tránh, cuồng nhiệt và mất ngủ $6,7]$. Đúng như dự đoán, NVYT̀ tuyến đầu gặp phải tình trạng đau khổ tâm lý hơn so với NVYT có vai trò thứ yếu [4].

Theo các nghiên cứu gần đây ở Việt Nam, NVYT trực tiếp chăm sóc bệnh nhân COVID-19 có dấu hiệu lo âu, trầm cảm và chất lượng cuộc sống suy giảm $[3,7]$. Tiếp xúc trực tiếp với cảm xúc tiêu cực ở mức độ cao dường như làm tăng nguy cơ dẫn đến hậu quả lâu dài như căng thẳng thứ phát, các triệu chứng trầm cảm hoặc kiệt sức nghề nghiệp với các kết quả bất lợi cho tổ chức. Tại Việt Nam, kể từ đâu năm 2020 khi ca bệnh COVID-19 đầu tiên được ghi nhận, dịch bệnh đã lây lan với diễn biến rất phức tạp, đặc biệt trong đợt dịch thứ 4 (từ ngày 27/04/2021) đợt dịch bùng phát mạnh mẽ tại các tỉnh thành phía Nam với số ca mắc và tử vong rất cao. Tính đến ngày $20 / 10 / 2021$, tổng số ca mắc tại Việt Nam trong đợt dịch thứ 4 là 865.558 với sổ ca tử vong là 21.344, thành phố Hồ Chí Minh (TP.HCM) là địa phương có số ca mắc cao nhất cả nước với 419.599 trường hợp [1]. Những con số này dự báo tình trạng căng thẳng ở nhân viên y tế rất cao trong bối cảnh sự hỗ trợ và chăm sóc sức khỏe tâm thần cho NVYYT còn hạn chế do nhiều nguyên nhân khác nhau. Nghiên cứu này nhằm mục đích đánh giá mức độ căng thẳng của nhân viên y tế và một số yếu tố liên quan tại một số bệnh viện điều trị bệnh COVID-19 tại TP.HCM nắm 2021.

\section{II. ĐỐI TƯỢNG VÀ PHƯƠNG PHÁP NGHIÊN CỨU 2.1. Đối tượng, địa điểm nghiên cứu}

Đối tượng nghiên cứu: gồm 244 NVYT tại các bệnh viện điều trị bệnh nhân COVID-19, bao gồm bác sĩ, điều dưỡng, kỹ thuật viên, nhân viên y tế khối hành chính và hậu cần.

Địa điểm: Nghiên cứu được triển khai tại 12 bênh viện và đơn vị y tế tuyến đâu điêu trị bệnh nhân COVID-19 tại TP.HCM bao gồm Bệnh viện Bình Dân, Bệnh viện Nhân Ái, Bệnh viện Nhẩn dân Gia định, Bênh viên Quận 11, Bênh viên Tân Tạo, Bệnh viện Chợ Rẫy, Bệnh viện Hùng Vương, Bệnh viện Từ Dũ, Bệnh viện Thành Phố Thủ Đức, Bệnh viện Trưng Vương, Nha khoa quốc tế Việt Mỹ, Sở Y tế Tp.HCM.

2.2. Thiết kế nghiên cứu. Thiết kế nghiên cứu mô tả cắt ngang được thực hiện từ ngày 13 đến ngày 20 tháng 9 năm 2021

2.3. Phương pháp thu thập số liệu. Một biểu mẫu khảo sát của Google đã được tạo theo bảng câu hỏi cấu trúc. Bảng câu hỏi này dựa trên bảng câu hỏi được phát triển dựa trên tham khảo bộ công cụ DASS-21 nhưng đã được điều chỉnh cho phù hợp với tình hình COVID-19 ở Việt Nam. Dữ liệu được thu thập ẩn danh. Những người tham gia đồng ý đã hoàn thành bảng câu hỏi và cung cấp các dữ liệu sau:

- Đặc điểm nhân khẩu học - xã hội: tuổi, giới tính, tình trạng hôn nhân, trình độ chuyên môn, thâm niên công tác, đơn vị làm việc, tình trạng thu nhập, sông chung với người dễ bị tổn thương (trẻ em <12 tuổi; người cao tuổi; người bệnh mãn tính).

- Điều kiện làm việc: số giờ làm việc/ngày, số ngày làm việc/tuần, công việc chính hiện tại, loại hình lao động, kiêm nhiệm chức vụ quản lý, thời gian tham gia chống dịch.

- Những áp lực của NVYT: bao gồm tần suất gặp áp lực từ phản ứng tiêu cực từ bệnh nhân, từ phản ứng tiêu cực từ gia đình bệnh nhân, từ gia đình do công việc liên quan đến COVID-19, áp lực thời gian hoàn thành công việc, áp lực do chứng kiến biến chứng nặng/tử vong do COVID-19.

- Mức độ căng thẳng: thành phần căng thẳng (7 câu hỏi) của thang điểm trầm cảm, lo lắng và căng thẳng (DASS-21) được sử dụng để đánh giá tình trạng căng thẳng. Điểm số được phân nhóm thành bình thường $(0-14$ điểm) và có căng thẳng (>14 điểm). Căng thẳng được phân thành 
các mức độ: mức độ nhe (15-18 điểm), mức độ trung bình (19-25 điểm), mức độ nặng (26-33 điểm) và mức độ rất nặng (>33 điểm) [6].

2.4. Phân tích số liệ̂u. Sử dụng phầm mềm SPSS 20.0 để phân tích số liệu. Những thông tin của nhân viên y tế được mô tả bằng tần số và tỷ lệ phần trăm cho biến phân loại; trung bình và độ lệch chuẩn cho biến liên tục. Phân tích hồi quy logistic đa biến được sử dụng để xác định các yếu tố liên quan đến căng thẳng nghề nghiệp ở nhân viên y tế với ngưỡng ý nghĩa thống kê $\mathrm{p}<0,05$.

2.5. Đạo đức nghiên cứu. Tính ẩn danh và sự đồng ý của đối tượng nghiên cứu đã được đảm bảo. Nghiên cứu đã được Hội đồng đạo đức bệnh viện Thành phố Thủ Đức cho phép chính thức theo công văn số 12/HĐĐĐ ngày 10/09/2021.

\section{KẾT QUẢ NGHIÊN CứU}

\section{1. Đặc điểm của đối tượng nghiên cứu}

Bảng 1. Đặc điểm nghề nghiệp của nhân viên y tế

\begin{tabular}{|c|c|c|c|}
\hline \multicolumn{2}{|r|}{ Đặc điếm } & $\mathbf{n}$ & $\%$ \\
\hline \multirow{2}{*}{$\begin{array}{l}\text { Trình độ chuyên } \\
\text { môn }\end{array}$} & Dưới đại học & 83 & 34,0 \\
\hline & Đại học/sau đại học & 161 & 66,0 \\
\hline \multirow{4}{*}{$\begin{array}{l}\text { Khối khoa/ phòng } \\
\text { đang công tác }\end{array}$} & Khối điều trị & 154 & 63,1 \\
\hline & Khối cận lâm sàng & 47 & 19,3 \\
\hline & Khối hậu cần & 17 & 7,0 \\
\hline & Khối hành chính & 26 & 10,7 \\
\hline \multirow{4}{*}{$\begin{array}{l}\text { Công việc chính } \\
\text { trong giai đoạn } \\
\text { chống dịch }\end{array}$} & Trực tiếp điều trị bệnh COVID-19 & 112 & 45,9 \\
\hline & $\begin{array}{c}\text { Xét nghiệm cộng đồng, hồ trợ công tác tiêm } \\
\text { chủng vắc xin COVİD-19 }\end{array}$ & 17 & 7,0 \\
\hline & Sàng lọc, truy vết COVID-19 & 19 & 7,8 \\
\hline & Hành chính, hậu cần, khác & 96 & 39,3 \\
\hline \multirow{2}{*}{$\begin{array}{l}\text { Công việc kiêm } \\
\text { nhiệm quản lý }\end{array}$} & Có & 54 & 22,1 \\
\hline & Không & 190 & 77,9 \\
\hline \multirow{2}{*}{ Loại hình lao động } & Biên chế & 156 & 63,9 \\
\hline & Hợp đồng & 88 & 36,1 \\
\hline
\end{tabular}

Đa số (66,0\%) có trình độ chuyên môn đại học trở lên, tỷ lệ NVYT thuộc khối điều trị cao nhất với $63,1 \%$, tiếp đến là khối cận lâm sàng với 19,3\%, khối hậu cần và hành chính là $17,7 \%$. Về công việc chính hiện tại, đa số NVYT trực tiếp tham gia điều trị bệnh COVID-19, tuy nhiên có tới 39,3\% NVYT làm công việ̣c hành chính hoặc hậu cần phòng chống COVID-19, có 14,8\% NVYT khác thực hiện công tác sàng lọc, truy vết dịch tễ, hỗ trợ tiêm chủng vắc xin COVID-19 hoặc làm công việc hậu cần, hành chính cho công tác phòng chống dịch COVID-19.

Bảng 2. Đặc điểm thời gian làm việc trong giai đoạn chống dịch của nhân viên y tế

\begin{tabular}{|c|c|}
\hline Đặc điểm & Trung bình \pm độ lệch chuẩn \\
\hline Thời gian tham gia chống dịch COVID-19 (tháng) & $4,7 \pm 8,0$ \\
\hline Số giờ làm việc trung bình/ ngày (giờ) & $10,3 \pm 5,1$ \\
\hline Số ngày làm việc trung bình mối tuần (giờ) & $6,7 \pm 6,0$ \\
\hline
\end{tabular}

Thời gian tham gia công tác phòng chống dịch COVID-19 của NVYT là 4,7 $\pm 8,0$ tháng. Số giờ làm việc trung bình mỗi ngày là $10,3 \pm 5,1$ giờ và trung bình mỗi tuần NVYT phải làm việc trong 6,7 ngày.

Bảng 3. Áp lực gập phải trong quá trinh phòng chống dịch của nhân viên y tế

\begin{tabular}{|c|c|c|c|}
\hline \multicolumn{2}{|l|}{ Đặc điểm } & $\mathbf{n}$ & $\%$ \\
\hline \multirow{3}{*}{$\begin{array}{c}\text { Áp lực từ phản ứng tiêu cực từ } \\
\text { bệnh nhân }\end{array}$} & İt khi/không & 16 & 6,6 \\
\hline & Thỉnh thoảng & 154 & 63,1 \\
\hline & Thường xuyên & 74 & 30,3 \\
\hline \multirow{3}{*}{$\begin{array}{l}\text { Áp lực từ phản ứng tiêu cực từ gia } \\
\text { đình bệnh nhân }\end{array}$} & İt khi/không & 33 & 13,5 \\
\hline & Thỉnh thoảng & 155 & 63,5 \\
\hline & Thường xuyên & 56 & 23,0 \\
\hline \multirow{3}{*}{$\begin{array}{l}\text { Áp lực từ gia đình do công việc liên } \\
\text { quan đến COVID-19 }\end{array}$} & İt khi/không & 27 & 11,1 \\
\hline & Thỉnh thoảng & 142 & 58,2 \\
\hline & Thường xuyên & 75 & 30,7 \\
\hline App lực thời gian hoàn thành & It khi/không & 23 & 9,4 \\
\hline
\end{tabular}




\begin{tabular}{|c|c|c|c|}
\hline \multirow{2}{*}{ công việc } & Thỉnh thoảng & 125 & 51,3 \\
\cline { 2 - 4 } & Thường xuyên & 96 & 39,3 \\
\hline \multirow{3}{*}{ Áp lực từ cấp trên } & İt khi/không & 49 & 20,1 \\
\cline { 2 - 4 } & Thỉnh thoảng & 147 & 60,2 \\
\cline { 2 - 4 } & Thường xuyên & 48 & 19,7 \\
\hline \multirow{2}{*}{$\begin{array}{c}\text { Áp lực do chứng kiến biến chứng } \\
\text { nạ̣ng/tử vong do COVID-19 }\end{array}$} & İt khi/không & 26 & 10,6 \\
\cline { 2 - 4 } & Thỉnh thoảng & 108 & 44,3 \\
\cline { 2 - 4 } & Thường xuyên & 110 & 45,1 \\
\hline
\end{tabular}

Tỷ lệ NVYT gặp các áp lực của trong công việc và cuộc sống khá cao, trong đó tỷ lệ thường xuyên gặp áp lực do chứng kiến biến chứng năng/tử vong do COVID-19 cao nhất với 45,1\%, tiếp đến là thường xuyên gặp áp lực thời gian hoàn thành công việc $39,3 \%$, thường xuyên gặp áp lực từ gia đình do công việc liên quan đển COVID-19 với 30,7\%, thường xuyên gặp áp lực từ phản ứng tiêu cực của bệnh nhân COVID-19 là $30,3 \%$, từ phản ứng tiêu cực của gia đình bệnh nhân là $23,0 \%$ và cuối cùng là thường xuyên gặp áp lực từ cấp trên với 19,7\%.

3.2. Tình trạng căng thẳng của nhân viên y tế

3.3. Một số yếu tố liên quan đến tình trạng căng thẳng của nhân viên y tế

Bảng 5. Một số yếu tố liên quan đến tỉnh trạng căng thẳng ở nhân viên y tế (Mô hình hồi quy logistic đa biến)

\begin{tabular}{|c|c|c|c|}
\hline Biến số & OR & 95\%CI & $\mathbf{p}$ \\
\hline Tuô̂i & 0,974 & $0,93-1,02$ & 0,287 \\
\hline Giới tính nữ & 1,066 & $0,51-2,19$ & 0,863 \\
\hline Công việc trực tiếp điều trị bệnh nhân COVID-19 & 2,137 & $1,01-4,53$ & 0,048 \\
\hline Kiêm nhiệm công việc quản lý & 1,180 & $0,48-2,91$ & 0,719 \\
\hline Sống cùng đối tượng dể tổn thương & 1,595 & $0,68-3,69$ & 0,275 \\
\hline Thường xuyên gặp áp lực từ bệnh nhân & 1,024 & $0,46-2,28$ & 0,953 \\
\hline Thường xuyên chịu áp lực từ cấp trên & 7,045 & $1,55-31,9$ & 0,011 \\
\hline $\begin{array}{c}\text { Thường xuyên chịu áp lực do chứng kiến trường hợp } \\
\text { nặng/tử vong }\end{array}$ & 1,807 & $0,82-3,95$ & 0,138 \\
\hline
\end{tabular}

Mô hình hồi quy logistic đa biến cho thấy có 2 yếu tố liên quan đến tình trạng căng thằng ở nhân viên y tế bao gồm: Tình trạng công việc hiện tại $(\mathrm{OR}=2,137,95 \% \mathrm{KTC} 1,01-4,53 ; \mathrm{p}=0,048)$ và chịu áp lực từ cấp trên $(\mathrm{OR}=7,045 ; 95 \% \mathrm{KTC}$ 1,55 - 31,9; $\mathrm{p}=0,011)$.

\section{BÀN LUÂN}

Nghiên cứu này đã tiếp cận được với 244 nhân viên y tế đang làm việc tại một số bệnh viện tại TP.HCM nơi là tâm dịch lớn ở Việt Nam và tác động rất nghiêm trọng đến cuộc sống của người dần. Kết quả đã cho thấy đại dịch COVID19 đã có những tác động đến sức khỏe tâm thần của các nhân viên y tế đặc biệt là các nhân viên y tế tham gia vào công tác điêu trị cho bệnh nhân COVID-19 tại các bệnh viện. NVYT bao gồm bác sĩ, điều dưỡng, kỹ thuật viên xét nghiệm, dược sĩ các chuyên gia y tế và tất cả các nhân viển hố trợ làm việc tại các bệnh viện nơi bệnh nhân COVID-19 được điều trị phải đối mă̆t với những thách thức và căng thẳng đáng kể. Ngoài những thách thức lâm sàng liên quan đến việc điều trị một lượng lớn bệnh nhân, NVYT làm việc với nhóm bệnh nhân lây nhiễm này phải đối mă̆t với các mối đe dọa về sức khỏe thể chất và tinh thần của chính họ [3]. Ngày càng có nhiều sự công nhận về tác động tâm lý đáng kể của việc chăm sóc những người bị COVID-19 đến nhân viên y tế. Trong nghiên cứu này có đến $83,0 \%$ nhân viên y tế bị căng thẳng, trong đó hơn 40\% ở mức độ nặng và rất nặng. Tỷ lệ này cao hơn gần gấp đôi so với một nghiên cứu của Võ Văn Thắng và cs (2020) trên 746 NVYT tuyến đầu tại tâm dịch Đà Nẵng, với $44,6 \%$ bị căng 
thẳng (gần 20\% ở mức độ nặng và rất nặng) [7]. Có thể do thời điểm tiển hành khảo sát dẩn đến sự khác biệt này. Nghiên cứu này tiến hành tai TP.HCM trong đợt dich COVID-19 thứ 4 (bắt đầu từ cuối tháng 4/2021), biến thể Delta của virus SARS-CoV-2 làm cho tỷ lệ lây lan ở cộng đồng nhanh hơn và trở nên trầm trọng [1], hàng ngàn ca mắc một ngày, số bệnh nhẩn nă̆ng và tử vong cao hơn rất nhiều so với thời điểm thực hiên khảo sát tại Đà Nẵng [7]. Trong một đánh giá hệ thống gần đây trên 35 bài báo với dữ liệu từ 25.343 NVYT, $56 \%$ trong số họ đã báo cáo mức độ căng thẳng cao ( $95 \% \mathrm{CI}: 32 \%-79 \%)$, thấp hơn nghiên cứu này [8]. Sự khác biệt về mức độ căng thẳng của NVYT giữa các nghiên do nhiều yếu tố, trong đó chắc chắn là quy mô đại dịch tại địa phương, các chính sách, nô lực của địa phương và quốc gia trong phòng chống dich bênh, đăc biệt là các mức đô hỗ trợ cho NVYT tuyến đầu chống dịch. Tình trạng căng thẳng của NVYT kéo dài không chỉ làm giảm hiệu suất lao động mà còn tăng nguy cơ bi rối loạn lo âu, trâm cảm, do đó việc chăm sóc sức khỏe cho NVYT, đặc biệt là chăm sóc sức khỏe tâm thần cho NVYT trong giai đoạn hiên nay là hết sức cần thiết. Hiện nay, tại Việt Nam, Bộ Y tế cũng đã ban hành "Hướng dẫn chăm sóc sức khỏe tâm thần trong dịch COVID-19" trong đó có NVYT để phòng chống sang chấn tâm lý trong dịch COVID-19 [2], tuy nhiên chưa có đánh giá đánh giá nào về việc thực hiện các hướng dẫn này.

Trong nghiên cứu này, tỷ lệ NVYT chịu áp lực thường xuyên từ cấp trên gần $20 \%$. Những NVYT này có nguy cơ bị căng thẳng cao hơn nhiều so với những đối tượng ít hoặc không chịu áp lực từ cấp trên $(\mathrm{OR}=7,05 ; 95 \% \mathrm{KTC} 1,55$ $31,9 ; p=0,011)$. Hiên tai TP.HCM đã chuẩn bi các chiến lược để chuyển sang giai đoạn bình thường mới, sống trong môi trường có COVID-19 và chuẩn bị thói quen, tinh thần để ứng phó với môi trường có virus. Yêu cầu mở cửa lại nền kinh tế, nới lỏng các điều kiện giãn cách là vấn đề tất yếu đối với TP.HCM khi sức chịu đựng của người dân và doanh nghiệp đã vượt ngướng. Nhân viên y tế có nguy cớ cao về các vấn đề sức khỏe tâm thần do tính chất làm việc của họ, tuy nhiên có một số bằng chứng cho thấy sức khỏe tâm thần của nhân viên y tế bị ảnh hưởng nhiều hơn do làm việc trong thời gian dịch bệnh COVID-19 bùng phát, đặc biệt ở nhóm tham gia điêu trị cho bênh nhân. Trong nghiên cứu của chúng tồi có đến $45,9 \%$ tham gia trực tiếp điều trị bệnh nhân và thời gian trung bình đảm nhiệm công tác trong thời gian bùng phát dịch của họ là hơn 4 tháng. Kết quả cũng đã cho thấy rằng những NVYT tham gia điều trị trực tiếp bệnh nhân COVID-19 có khả năng bị căng thẳng cao hơn so với những nhóm công việc khác như hành chính, hậu cần $(\mathrm{OR}=2,14,95 \% \mathrm{CI}: 1,01-4,53 ; p=0,048)$, các nghiên cứu của Nguyễn Thanh Thảo và cs (2021) hay Yan H (2021) cũng có thấy rằng làm việc trong bệnh viên và tiếp xúc trực tiếp với bênh nhân COVID-19 có liên quan đến nguy cơ cao bị căng thẳng ở nhân viên y tế $[3,8]$.

\section{KẾT LUÂNN}

Căng thẳng thường xảy ra đối với NVYT tuyến đầu trong đợt bùng phát COVID-19 ở thành phố Hồ Chí Minh. Họ đóng vai trò quan trọng trong việc chống lại đại dịch COVID-19, do đó việc thực hiện các chiến lược để cải thiên sức khỏe của NVYT là vô cùng quan trọng. Cần giảm thời gian làm việc và tăng cường chính sách đảm bảo an toàn môi trường bệnh viện, đặc biệt quan tâm nhiều hơn cho NVYT tiếp xúc trực tiếp với bệnh nhân COVID19 trong quá trình chẩn đoán và điêu trị.

\section{TÀI LIÊU THAM KHẢO}

1. Bộ Y tế (2021), Bản tin dịch COVID-19 ngày 4 tháng 10 năm 2021, Hà Nội, truy cập ngày 04/10/2021, tại trang web https://moh.gov.vn/tinlien-quan/-/asset publisher/ vjYyM709aWnX/ content/ngay-4-10-co-5-383-ca-mac-moi-covid-19rieng-tp-hcm-la-2-490-ca.

2. Bộ Y tế (2021), Quyết định số 2057/QĐ-BYT ngày 14 tháng 5 nắm 2020 của Bộ Y tế về việc ban hành tài liêu chuyên môn Hướng dẫn chăm sóc sức khỏe tâm thần trong dịch COVID-19, chủ biên, Hà Nội.

3. Thanh, N.T., Thanh, L.X.T., Thi, N.N.T. et al. (2021), "Psychosocial Impacts of COVID-19 on Healthcare Workers During the Nationwide Partial Lockdown in Vietnam in April 2020", Frontiers in psychiatry. 12

4. Chan, A.O. và Huak, C.Y. (2004), "Psychological impact of the 2003 severe acute respiratory syndrome outbreak on health care workers in a medium size regional general hospital in Singapore", Occupational medicine. 54(3), tr. 190-196.

5. Conversano, $C_{.}$Marchi, L. và Miniati, $M$ (2020), "Psychological distress among healthcare professionals involved in the covid-19 emergency: vulnerability and resilience factors", Clinical Neuropsychiatry. 17(2).

6. Lovibond, S. và Lovibond, P. (1995), "Manual for the depression anxiety stress scales. 2nd edn. Sydney: Psychology Foundation, 1995", Google Scholar, tr. 4-42.

7. Nhan, N., Dinh, L.D., Colebunders, R. et al. (2021), "Stress and associated factors among frontline healthcare workers in the COVID-19 epicenter of Da Nang city, Vietnam", Research Square(Version 1), tr. 1-12.

8. Yan, H., Ding, Y. và Guo, W. (2021), "Mental Health of Medical Staff During the Coronavirus Disease 2019 Pandemic: A Systematic Review and Meta-Analysis", Psychosomatic Medicine. 83(4), tr. 387-396. 